\title{
The innovative potential of inbound tourism in Japan for destination development - a case study of Hida Takayama
}

\author{
CAROLIN FUNCK
}

\section{Abstract}

In contrast to the rapid development of outbound tourism since the 1980s, inbound tourism has played a minor role in Japan until 2002, when the Japanese government embarked on a policy of active enticement of foreign tourists. Through active promotion and pushed by economic development in neighboring countries, visitor numbers almost doubled from 4,771,555 in 2001 to 8,350,835 in 2008; since then, worldwide economic downturn, disaster, and a soaring yen have taken their toll. However, while their contribution to the overall Japanese tourism market is still well below $10 \%$, an analysis of available data shows that foreign tourists are spread unevenly across the country. As a result, some restricted inbound clusters have evolved. In these places, inbound tourism as a new sector of the tourism market can play an important role in rejuvenation of destinations and innovation in tourism. One such destination is Hida Takayama, a historical town tucked away in the mountains of Gifu Prefecture, which is considered a model for the development of inbound tourism in Japan. An analysis of Takayama's tourism development process identified close cooperation between the public and private sector, the integration of inbound promotion into a wider set of tourism policies, and the combination of independent efforts by the city with active use of national policies as important factors for its formation as an international destination. As a result, the city attracts tourists from a variety of regions. A survey conducted with Japanese and different groups of foreign tourists proved that they differ in motivations and behavior and, therefore, add a stabilizing element to the tourism market. Finally, interviews with key persons from tourism associations and the accommodation industry, and a survey of small-scale businesses to examine innovations induced by the increase in foreign tourists showed that an active embracement of the new market segment is restricted to a 
small number of facilities. Through these steps of analysis, it could be shown that the impact of international tourism on destinations in Japan is limited to a number of places, where it nevertheless constitutes an important element of market stabilization and rejuvenation. However, its influence and potential for innovation are confined to some facilities within the destination, while the many small businesses forming the tourism industry often react in a passive way.

Keywords: Japan; innovation; tourist destination; inbound tourism; Takayama.

\section{観光地開発におけるインバウンド観光のイノベーション能力 日本の飛騨高山を事例に}

カロリン・フンク

1980年代以降の日本の海外旅行産業の急速な発展に対し、インバウン ド観光は2002年に政府が積極的な外国人観光者の誘致政策に乗り出す まで、副次的な役割を果たす程度であった。この積極的な促進政策に より、また周辺諸国の経済発展にも押され、日本への観光者数は2001 年の 477 万 1555 人から 2008 年の 835 万 835 人へとほぼ倍増している (これ以後、世界規模での経済の落ち込み、東日本大震災、円高が深刻 な打撃を与えることになるが）。それでも日本の観光産業全体に対す る貢献率はまだ十パーセントを下回っているが、既存統計によれば外 国人観光者は日本国内で不均等に点在していることが明らかになる。 その結果、いくつかの局所的なインバウンド観光地が形成されている。 これらの地において、インバウンド観光は観光市場の新しい分野とし て当該地域の再活性化、そして観光産業におけるイノベーションにお いて重要な役割を果たしている。そのような観光地の一つは岐阜県の 山間に隠れている飛騨高山であり、そこは日本のインバウンド観光の 発展モデルとみなされている。同地の観光の発展過程を分析してみる と、公的と民間機関の間の密接な協力や、インバウンド観光の促進を 幅広い観光政策に統合したこと、また国の政策を積極的に活用し、そ れを市独自の努力と組み合わせたといった、国際的な観光地として確 立するための重要な要因を見ることができる。その結果、高山市は様 々な地域からの観光者を集めることに成功している。日本人、および 異なる外国人観光者グループに対し実施した調査によれば、彼らの動 機、行動は異なっており、それ故、観光市場において安定要因になる ことが分かった。最後に、観光産業団体、および宿泊産業の関係者へ のインタビュー、ならびに外国人観光者の増加に対する新たな取り組 みを考察するために行われた小規模企業への調査によれば、新しい市 場分野の積極的な取り込みはいくつかの施設に限られていることが明 
らかになった。この分析の手順を通じ、日本の観光地への国際観光産 業のインパクトはいくつかの観光地に限定されており、それら地域で は市場の安定と活性化の重要な要因となっていることを示すことがで きたと考える。しかし、その影響、そしてイノベーションを引き起こ す能力はそれぞれの観光地においていくつかの施設に限定され、観光 産業を形成する多くの小規模な企業はしばしば受動的な反応を見せて いる。

\section{Introduction}

Japan's pattern of international tourism is quite peculiar. Other large tourist-generating economies with a strong domestic market such as the United States, Germany, France, and Britain also have a thriving inbound tourism market. Japan, on the other hand, ranks among the top ten countries for tourist departures and spending, but sits somewhere around the 30th rank for the number of incoming visitors. However, the number of inbound tourists had been growing almost constantly until 2008. Inbound tourism therefore can be considered a new, growing sector of the Japanese tourism market that in consequence will influence the development of tourist destinations.

This paper discusses the role of inbound tourism on the local level from two aspects - as part of a rejuvenating or restructuring process of stagnating destinations and as a trigger for innovation in tourism policies and tourism industries.

\section{Rejuvenation and innovation in tourist destinations}

Tourism development in destinations is not a continuous process; it happens in stages. The most famous description of these stages, built upon the product life cycle, is probably Butler's (1980) model of a "tourism area life cycle" (TALC). The five basic stages of "Exploration", "Involvement", "Development", "Consolidation", and "Stagnation" are distinct by numbers and types of tourists, facilities and attractions provided, types of investment, and significance of tourism for the economic and social life of residents. Further research has emphasized the role of tour operators, governments, and concentration in the tourism industry as factors that might induce a tourism area to another stage (Lagiewski 2006: 47). Once a destination has matured to the stage of stagnation, it can either face "Decline" and finally the abandonment of tourism or succeed in "Rejuvenation".

Although tourism worldwide is seen as a growth sector, the constant emergence of new destinations (i.e., new competition) and the saturation of some markets has made stagnation a realistic threat for tourism 


\section{Carolin Funck}

areas in highly developed markets. Therefore, rejuvenation has received considerable attention in research and policymaking (Cooper 2006: 200). As possible strategies, Agarwal (2002) mentions product reorganization through investment, technical change, coordination of strategies, and product specialization on the one hand and product transformation through service quality enhancement, environmental quality enhancement, repositioning, diversification, collaboration, and adaption on the other. She also points out that decline is a constant threat through all stages of the life cycle, and that the process of rejuvenation is a continuous one.

Rejuvenation thus requires constant innovation so a tourism area can also be considered a regional innovation system (Hall and Williams 2008: 160). However, regional systems differ greatly in their ability to bring about innovation. Tourism is generally seen as part of an imitative innovation policy that relies on input from other sectors or places rather than as a genuine innovative sector. For example, Hjalanger (2002: 470) points to the fact that innovations are rare in the tourism sector. The dominance of micro and small enterprises, the fact that most innovations are easily visible and open to imitation, that enterprises within destinations rarely cooperate, and that the workforce receives little training and has a high turnover rate, are cited as obstacles to innovation. Knowledge necessary for innovations, therefore, relies on outside channels. Trade organizations on all levels from the global to the local level, technologies developed in other sectors, infrastructure like tourism resources or transport systems managed by public authorities and regulations all serve as sources of knowledge and inspiration for innovation in tourism.

While tourism shares many features with other service industries, some characteristics make tourism different. Hall and Williams (2008: 15) consider complexity, temporality, and spatiality of the tourist experience, as well as encounters between tourists and the tourism industry and between tourists and host communities as distinctive features of tourism that influence innovation. As a consequence, innovations occur in different parts, stages, places, and relations of the tourism experience, are induced by various actors, and refer to different scales. For example, the decision to embark on a strategy to promote inbound tourism on the local level through the designation of International Tourism Model Districts in the 1980s was made on the national scale but accepted on the local; it provided tourists with information at their destination and also before their trip, and involved a series of actors from the tourism industry as well as the public sector. Under these conditions, a typology of innovations would be a futile attempt. Therefore, attention has to be turned rather to the possibilities of one market 
segment - inbound tourism - to trigger innovations and to contribute to the process of rejuvenation.

Japan, as a highly developed tourism market with a long history, is home to many mature or even deteriorating tourist destinations. The famous spas with their clusters of concrete hotels and entertainment facilities built for company recreation and other group tours in the 1960s are the most prominent example, but destinations that emerged in the 1970s to offer rustic charm for tired urbanites now share a similar fate. The highly predictable domestic market of the 1960s and 1970s was replaced by a more individualistic one in the 1980s and 1990s (Funck 1999), but was still protected from any outside influences in the form of tourists and capital. Only a few destinations embarked early on the innovative idea of attracting foreign tourists, which gave them a head start when national politics finally discovered the subject in 2002. This paper takes up one such destination, the city of Hida Takayama in Gifu Prefecture, to examine how inbound tourism influences processes of rejuvenation and innovation.

As a background for the destination study, an outline of the development of Japan's inbound policies and an analysis of inbound tourism statistics to reveal regional distribution patterns will be presented. The example case of Hida Takayama will then be examined from three aspects: tourism policies and promotion in the context of rejuvenation processes, the characteristics of domestic and international tourists, and their potential as a factor of diversification and innovation strategies of the tourism industry.

\section{Methodology}

This paper draws on a variety of sources and methods to create a complex picture of destination development through inbound tourism. Tourism statistics form the background of the section on inbound tourism. For a country with an elaborate statistical system, Japan's tourism statistics are surprisingly haphazard. Immigration statistics are edited and published by the Japan National Tourist Organization (JNTO). However, once inside the country, movements of foreign tourists are difficult to track. Three sources of information are available. First, the annual survey by JNTO on visited destinations (Hōnichi gaikyaku hōmonchi chōsa) (JNTO 2010a) asks visitors at the point of departure from Japan to name the destinations they have visited and covers about 15,000 tourists each year. However, problems of recall and unfamiliarity with place-names suggest that only a small section of destinations are picked up. Second, the "Overnight trip statistics survey" (Shuku- 
haku ryokō tōkei chōsa), conducted by the government annually since 2007 (MLIT 2007-2011), gathers information from accommodation facilities across the country. Third, destinations collect data on foreign tourists, but quality and detail differ greatly in each location and the classification as foreign tourist is often based on visual judgment only. In the case of Takayama, data on foreign tourists are acquired from accommodation facilities and are therefore more reliable.

The development of Takayama as an international tourist destination has been the target of several research papers in Japanese; recent examples include Tsuda (2004), Tsuchida and Hanyu (2006), Tanizawa (2005), and Dai (2009). Material provided by the city administration as well as regional and national newspapers served as additional sources to outline tourism policies and promotion in the process of development.

To make up for the above-mentioned shortfalls in official tourism statistics, a survey of visitors to Takayama was conducted in November 2010 to confirm differences in behavior, motivation, and destination images among tourists of different origins. Questionnaires in Japanese, English, Chinese (mainland and Taiwanese writing), and Korean were distributed; however, it was very difficult to obtain responses from Asian tourists as most of them travel in tour groups with a tight schedule. Therefore, the analysis of the 410 respondents was based on three groups: Those who filled out the Japanese questionnaire and had almost exclusively Japanese nationality (245 respondents), those who choose the English questionnaire (106 respondents), and those who choose one of the Asian languages (59 respondents).

Finally, innovations in the tourism industry were investigated through a mix of quantitative and qualitative methods. A survey of 100 shops and small-scale facilities in different parts of the central and tourism district gives an overview of the degree of involvement with inbound tourism, while in-depth interviews of accommodation facilities with a large segment of foreign customers clarify the actual process of "getting involved". The survey was conducted in November 2010, interviews on three visits in 2007, 2008, and 2010.

Hida Takayama was chosen as an example, because a consequent engagement in tourism policies throughout fluctuations in tourist numbers, a variety of attractions, a diversified tourism industry, and an inbound sector drawing on different nationalities make it an ideal case study for rejuvenation strategies and the innovative role of inbound tourism. In Japan, Takayama is considered a best-practice example for tourism area management, especially management of heritage, inbound tourism, and universal design. 


\section{Inbound tourism and its regional patterns}

Soshiroda (2005) divides Japan's inbound policy into five phases. During the two phases before World War II, the government aimed to use inbound tourism policies to raise the international status of Japan and to gain foreign currency. After World War II, phases of inbound promotion (1945 to 1970 and 1996 until present) alternated with a period emphasizing outbound travel (1970 to 1996). Directly after the war, inbound tourism was promoted to bring foreign currencies into the country, but also to establish a new image for Japan as a peaceful nation. The Tokyo Olympic Summer Games in 1964 were an excellent opportunity to spread the image of Japan around the world, so the Japan National Tourism Organization (JNTO) was established for this purpose. However, when traveling abroad was liberalized in the same year, outbound trips began to increase. The rise of the yen since 1985 and the following years of economic upturn led to a rapid growth in travel abroad, whereas the image - and its reality in Tokyo - of Japan as an immensely expensive country suffocated inbound tourism. Generally, during this phase, outbound tourism dominated realities and policies. The designation of International Tourism Model Districts in 1986 and International Convention Cities in 1988 was an exception. These can be seen as attempts aimed at bringing foreigners, foreign goods, and the possibility of travel abroad, to every village within the framework of internationalization, a central concept of that period. These efforts notwithstanding, the gap between inbound and outbound tourism widened considerably during the 1980s. The resulting imbalance was actually welcome at the time, as the deficit in tourism helped to adjust Japan's trade surplus. It only began to be perceived as a problem in the late 1990s.

Since the 1990s, the continuous economic growth in neighboring Asian countries and the deflation that plagued Japan during its "lost decade" have made the country a more affordable destination. In 1997, a law concerning the attraction of foreign tourists introduced three sets of measures: the establishment of Theme Districts for International Tourism that would be promoted specially by JNTO, regionally restricted Welcome Cards that offer foreign tourists price reductions, and new qualifications for tour guides on a regional basis that would not require passing the national tour guide exam. These ideas finally connected to the new inbound policy of the early 2000s.

Under the Koizumi administration, for the first time inbound tourism was emphasized as an important policy, which found its expression in the "Yokoso! Japan" campaign and later in the establishment of the Tourism Agency within the MLIT in 2009. In the economic strategy set 


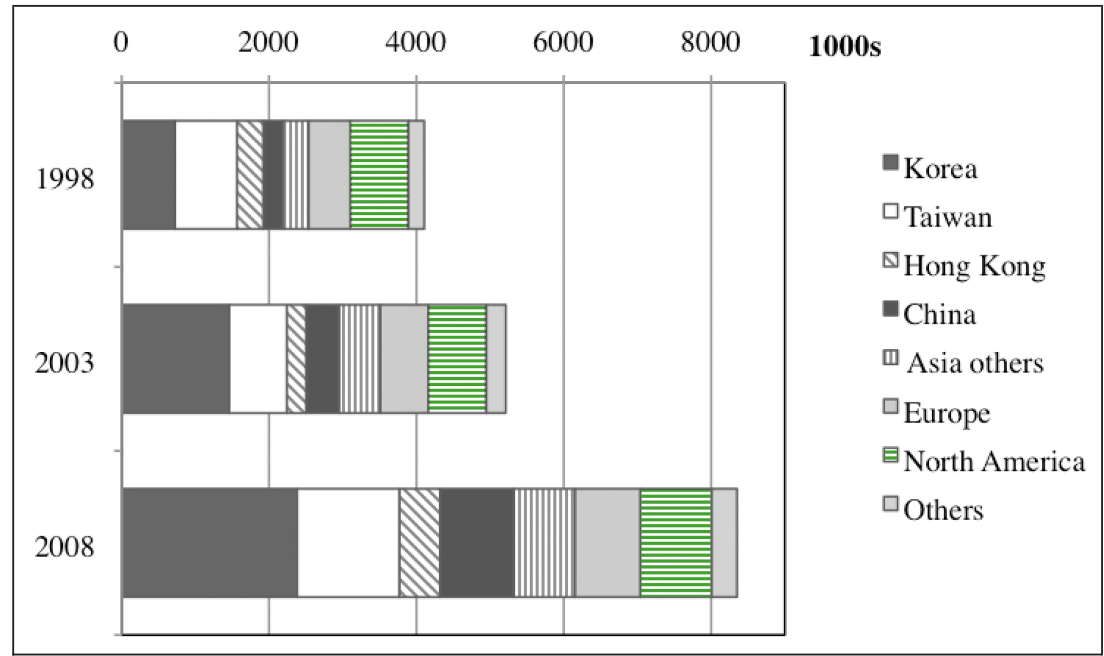

Figure 1. Inbound tourists by region of origin in 1998, 2003, 2008 (in thousands). Source: JNTO (1999, 2004, 2009).

by the cabinet for 2002, tourism, especially inbound, was part of the action program to revitalize the economy. The aims of promoting inbound tourism were to contribute to international understanding, trigger economic revitalization, and enhance confidence and pride in local communities and their culture. Three basic strategies were outlined: (i) promotion; (ii) sophistication of the tourism industry; and (iii) improving visitor reception structures concerning information, transportation, and destinations. The Visit Japan Campaign was started in 2003, aiming at ten million visitors from abroad by 2010. As a consequence of active promotion in key markets, but also due to the economic development in neighboring countries, visitor numbers almost doubled from $4,771,555$ in 2001 to $8,350,835$ in 2008 . However, due to the economic depression after the "Lehman shock" in 2008, influenza fears in spring 2009 , the free fall of most currencies against the yen, as well as political problems with China in autumn 2010, the goal has not been reached (see Figure 1). In March 2011, the triple catastrophe of earthquake, tsunami, and nuclear radiation brought inbound tourism almost to a standstill; by August 2011, numbers had recovered to reach $32 \%$ of 2010.

The increase in numbers was accompanied by an increase in repeat visitors who spread to more remote destinations. Charter flights and cruises to regional airports and ports have contributed to this tendency (Kitamura 2007: 127), although immigration statistics show only a slight 
Table 1. Top five prefectures for overnight stays of foreign tourists by area of origin (in 2009).

Source: MLIT Tourism Agency (2010a).

\begin{tabular}{llllll}
\hline & Rank 1 & Rank 2 & Rank 3 & Rank 4 & Rank 5 \\
\hline Korea & Tokyo & Osaka & Hokkaido & Fukuoka & Kumamoto \\
China & Tokyo & Osaka & Chiba & Hokkaido & Yamanashi \\
Hong Kong & Tokyo & Hokkaido & Osaka & Chiba & Okinawa \\
Taiwan & Hokkaido & Tokyo & Osaka & Chiba & Aichi \\
USA & Tokyo & Chiba & Osaka & Kyoto & Kanagawa \\
Great Britain & Tokyo & Chiba & Kyoto & Osaka & Kanagawa \\
Germany & Tokyo & Kyoto & Chiba & Osaka & Kanagawa \\
France & Tokyo & Kyoto & Osaka & Kanagawa & Hiroshima \\
Singapore & Tokyo & Hokkaido & Chiba & Osaka & Yamanashi \\
Thailand & Tokyo & Osaka & Aichi & Yamanashi & Chiba \\
Australia & Tokyo & Chiba & Kyoto & Osaka & Hokkaido \\
\hline
\end{tabular}

increase in dispersion to airports outside Tokyo, Nagoya, and Osaka between 2003 and 2009 (JNTO 2004, 2010b).

A look at the JNTO survey on visited destinations reveals that the top five ranks with visitation rates above $10 \%$ have been occupied by the same five prefectures - Tokyo, Osaka, Kyoto, Kanagawa, and Chiba - for years. However, in each market segment, other prefectures make occasional appearances - such as Fukuoka for Koreans, Hokkaido for visitors from Taiwan and Hong Kong, Nara for French and German tourists (JNTO 2010a: 13-26). A similar pattern can be seen in the Shukuhaku ryokō tōkei chōsa ('Overnight trip statistics survey') (MLIT Tourism Agency 2010a). While the top five ranks for all tourists are the same as in the JNTO survey, in different market segments the top five prefectures include Fukuoka and Kumamoto for Koreans, Hokkaido and Yamanashi for Chinese and Singaporeans, Hokkaido for tourists from Taiwan, Hong Kong, and Australia, and Aichi for Taiwanese and Thai. And in Tokyo, Osaka, Chiba, Yamanashi, and Kyoto, foreigners account for more than $10 \%$ of all overnight stays, thus forming a significant market segment (see Table 1).

Below rank 15 in the JNTO survey, prefectures were visited by less than $2 \%$ of all respondents to the survey. However, when broken down to the local level and restricted to leisure and vacation tourists, some destinations show much higher visitation rates. Hiroshima City, visited by $5 \%$ of total, $27 \%$ of German, $23 \%$ of French, and $22 \%$ of British tourists is one example; Takayama City with $3 \%$ of total, $4.3 \%$ of Taiwanese, $7.2 \%$ of French, $6.7 \%$ of German, and $7.4 \%$ of British tourists is another. Niseko in Hokkaido attracts $13.4 \%$ of Australians as a destination highly specialized for activity - skiing - as well as nationality. 
Some destinations such as Hiroshima apply to one market segment, Western tourists, while others like Takayama have a wider appeal.

It is estimated that inbound tourism accounted for just about $6.3 \%$ of all travel expenses in the domestic market in 2007 (MLIT Tourism Agency 2009: 78). While inbound tourism might thus be considered still a negligible market segment for Japan as a whole, its importance for certain destinations should not be underestimated. In these areas or places, inbound tourism could play a crucial role in the stabilization and diversification of demand and even trigger new developments and innovations in tourism.

\section{Inbound tourism policies and promotion in the development process of Takayama}

Takayama City in Gifu Prefecture is one destination where inbound tourism plays a highly visible, important role as a segment of the overall tourism area development process. Takayama City, commonly known as Hida Takayama, has about 67,000 inhabitants and is located in the central region of Japan at the foot of the Japanese Alps, two

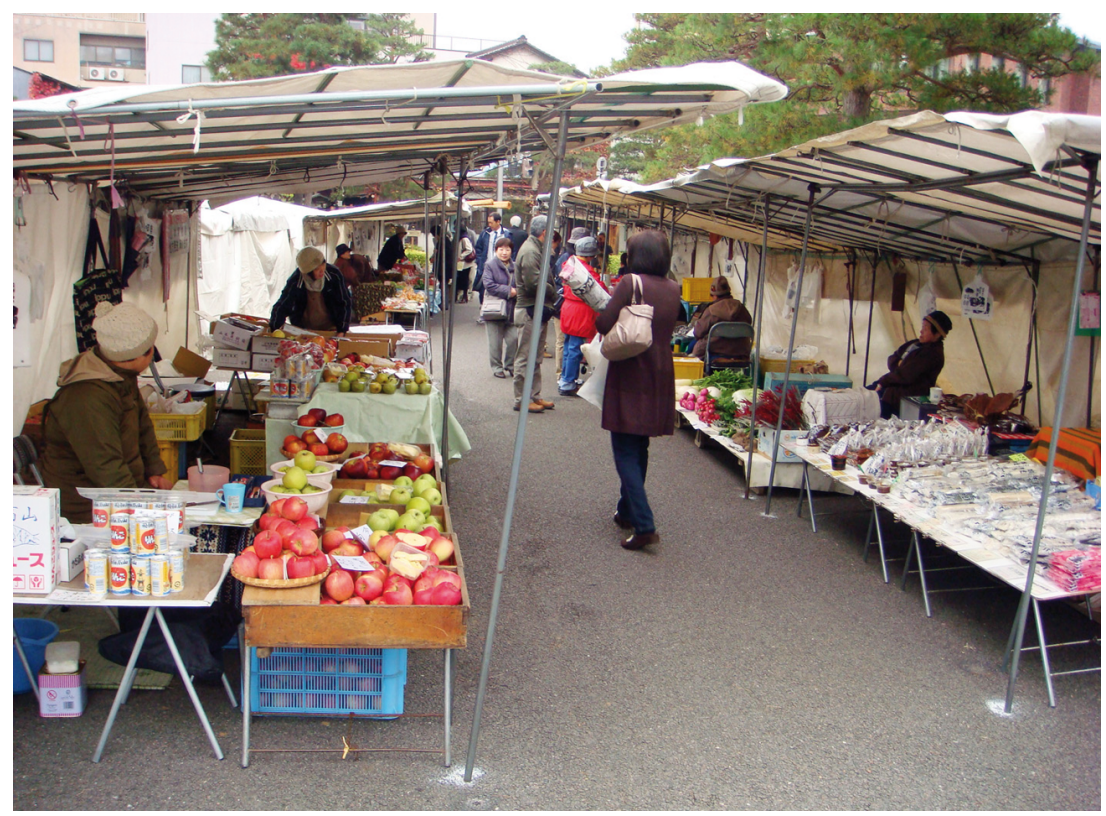

Figure 2. Two morning markets with local products attract many tourists to Takayama. 


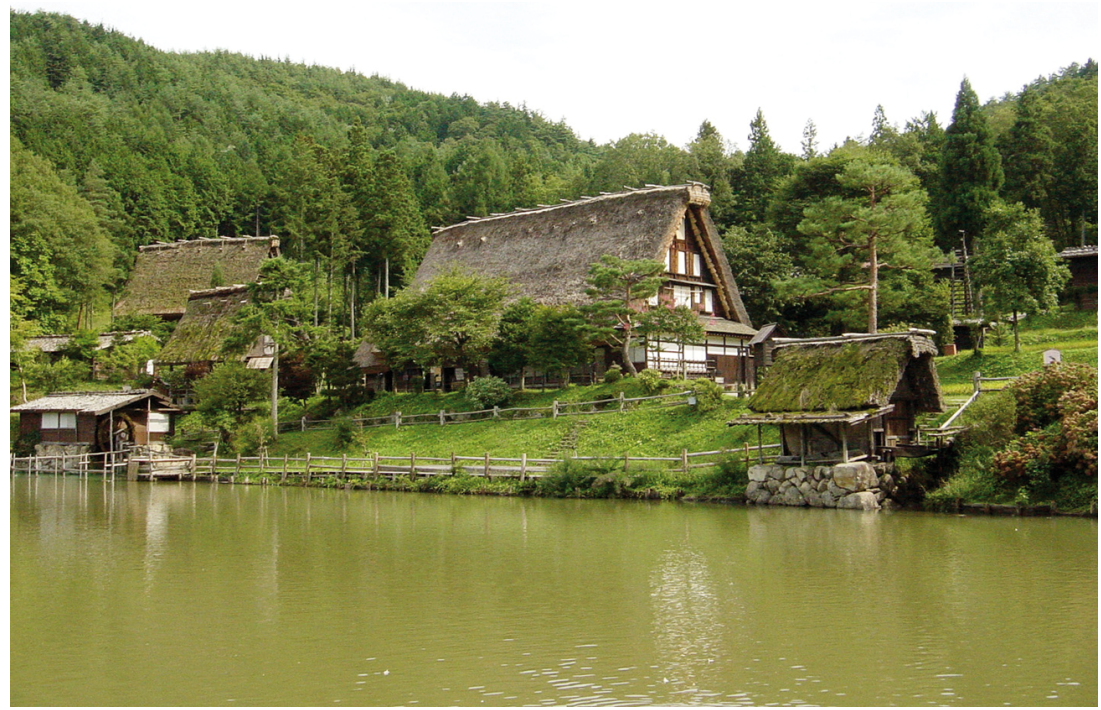

Figure 3. Hida no Sato features a collection of traditional farmhouses from around the area.

hours by train from Nagoya. To cite the Lonely Planet (2007: 255), "Takayama is a rarity: a 21st-century city that's also retained its traditional charm". Rewarding it with the attribute of "a place of harmony", Michelin's Green guide to Japan (2010: 406) rates the city three stars for its unique combination of old merchant and temple quarters, morning markets, festivals, and museums. It has always served as a gateway to the Japanese Alps and, with the completion of a highway in 2008, now functions as a base for trips to Shirakawa Village, registered as World Cultural Heritage for its gable-roofed thatched houses.

Takayama's main attractions are two annual festivals featuring gorgeous floats decorated with moving puppets, a large and well-preserved townscape district with many temples, small museums and shops to discover, the impressive buildings of a former administration complex (Takayama Jin'ya) dating back to the Edo Period, the former castle site, two morning markets with local products (see Figure 2), and traditional woodcraft. This central part of the city is within easy walking distance from the station and can be discovered on "leisurely strolls".

A large outdoor folk museum (Hida no Sato, see Figure 3) with a collection of old farmhouses in a spacious park-like setting and a range of new museums covering almost everything from European art to tea ceremony are located in the suburbs. On top of this, tourists are sup- 
ported by a wide array of accommodation facilities and restaurants catering for all tastes and budgets. In 2005, Takayama merged with nine surrounding municipalities, thus making it the largest city in Japan and adding a variety of hot springs, waterfalls, and hiking courses to its tourist resources.

Until the late 1960s, the city was in an "Exploration" phase, when small numbers of domestic visitors passed through on their way to the Japanese Alps. As can be seen from tourist numbers (Figure 4), when the city was discovered as a tourist destination in its own right in the early 1970s, a steep increase in visitor numbers occurred and the city passed quickly from the "Involvement" to "Development" phase in Butler's TALC model. After a period of "Stagnation" until the late 1980s, numbers have fluctuated with a long-term tendency to increase. Within the long-term process of "Development" and "Solidification", we can therefore identify smaller cycles of "Stagnation" and "Rejuvenation".

Overall visitor numbers (see Figure 4) grew with ups and downs from 2,080,000 in 1993 to 3,118,000 visitors in 2008 and have since fallen slightly to 2,817,000 (Takayama-shi Shōkō Kankō-bu Kankō-ka 2011). Most of the recent increases in numbers have been induced by changes in access, such as the construction of new highways or tunnels. On average, $44 \%$ of visitors stay overnight. Due to Takayama's remote location, this is a much higher percentage than in other destinations. The number of foreign overnight visitors to Takayama City, on the other hand, increased almost steadily from 23,766 in 1993 to 161,000 in 2010, and thus constitutes a stabilizing element in the development process. The percentage of foreigners to all overnight tourists grew accordingly from $2.2 \%$ in 1993 to $13.6 \%$ in 2010 . They now form an important segment of the market and offer the additional advantage of traveling outside Japanese holidays and weekends. While international tourists therefore only account for a few percent of all visitors, they are highly visible and are provided with public infrastructure including multilingual signs and private services like accommodation or restaurants. The multilingual Web site supported by the Takayama Tourism Association advertises the city in eleven languages as a place with the feeling of a castle town, of an ancient city. In a monitor tour with twelve foreign residents in Japan conducted by the city in 2006, five participants praised the friendliness toward foreign visitors, four called it real, authentic Japan, and the remaining three also made positive remarks about the traditional townscape (Hida Takayama-shi Tōkyō Jimushō 2006). Hida Takayama can thus be classified as a destination representing "traditional" Japan, with the additional attraction of easy access to the Japanese Alps and Shirakawa Village. 


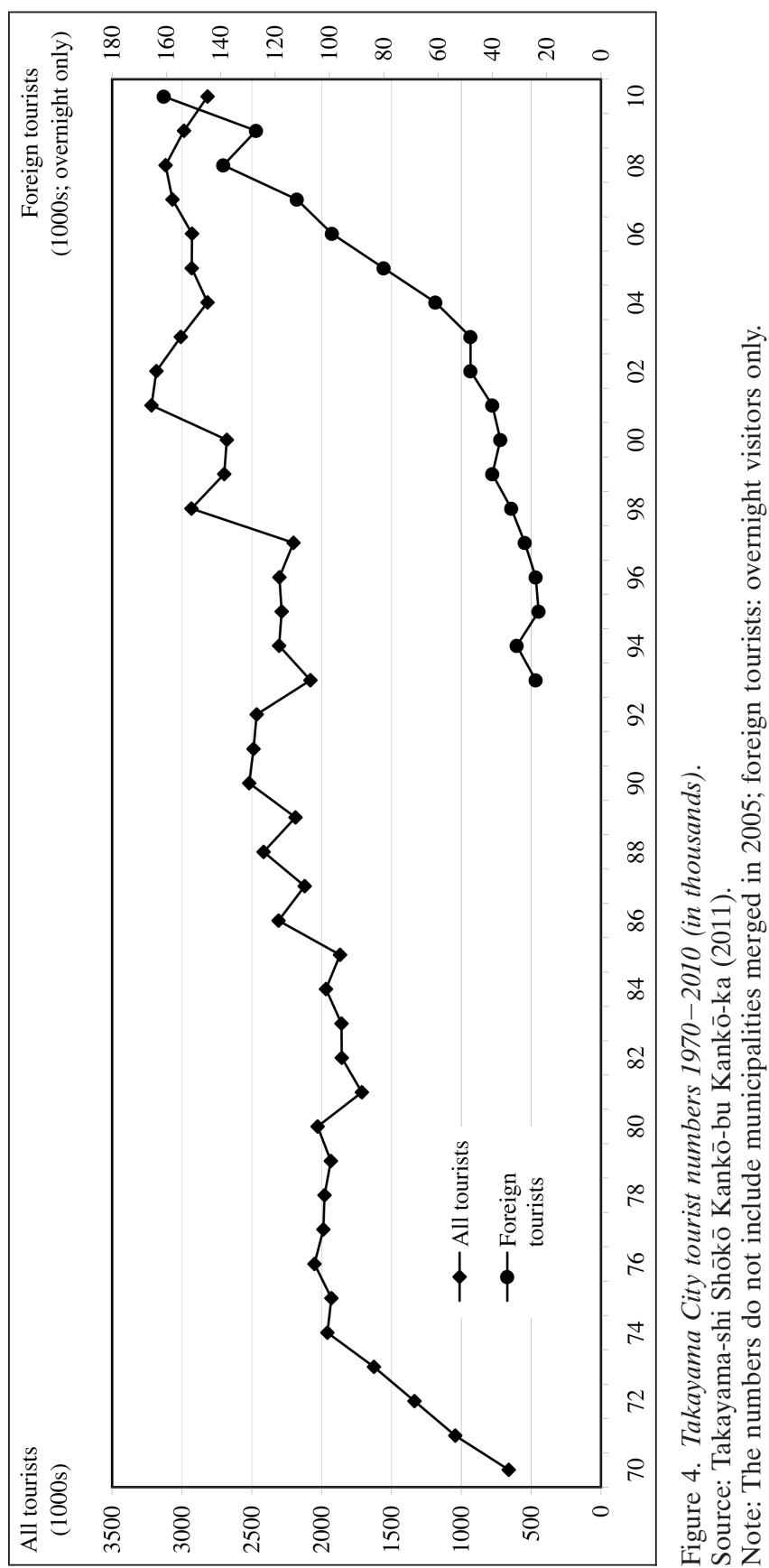




\section{Carolin Funck}

The same traditional atmosphere attracted Japanese tourists in the 1970s, when traditional townscapes were rediscovered in an age of rapid urban development. Takayama first received national attention in a magazine article about "the town behind the mountains" in 1963. The National Railway's "Discover Japan Campaign", a campaign to promote hardly known destinations across the country, brought one million visitors in 1971. The establishment of the outdoor folk museum Hida no Sato, with its spectacular array of old houses gathered from around the region and its designation of Preservation Districts for Groups of Historic Buildings in the city center, laid the groundwork for a sustainable management of historical resources. This management is based on citizen activities starting in the 1950 s to preserve the traditional Takayama festival, traditional townscapes, and the river landscape; these activities, in turn, are grounded in local community organizations to run the festival and prevent fires that date back as far as the Edo Period (Tanizawa 2005).

Organized tourism management based on cooperation between the public and the private sectors was established in 1982 when the Takayama Tourism Association changed its status from a voluntary organization to a corporation. A decline in visitor numbers due to heavy snow was the reason behind this move, as tourism industry actors realized the vulnerability of their industry and the need for constant promotion efforts (MLIT Tourism Agency 2010b). The ensuing close cooperation between the Tourism Association and the tourism section of the city administration is one factor cited in the success of Takayama's tourism policies (Tsuda 2004: 40). In consequence, the long-term leader of the Tourism Association was named one of 100 "tourism charisma" personalities by the national government in 2005. The reason for his selection was his efforts for continuous tourism development (MLIT Tourism Agency 2010b).

In the private sector, the 1990s saw the development of several new museums in the suburbs by local and regional investors that helped diversify tourism attractions but also may have diluted the image of Takayama as a historic town. At the same time, hotels began to replace traditional ryokan (Japanese inns) and minshuku (Western-style pensions), although the numbers of Japanese-style accommodation houses is still high for a city of this size.

Using this background of development as a domestic tourist destination based on its well-preserved townscape and festivals, the city started to promote international tourism early on. Takayama City makes a rather high budget available for tourism promotion; Englishlanguage pamphlets and maps as well as a manual in five languages for tourist facilities on how to communicate with foreign tourists were 
created in the 1980s. In 1986, the city was designated as an International Tourism Model District. Signage throughout the tourist district and the establishment of an international tourist information center in front of the station made it easy for foreign tourists to discover the city on their own. The following year saw the founding of Hida Takayama International Association, dedicated to making Takayama a "truly internationalized place" through language courses for residents, English speech contests, volunteer homestays, and guide programs (Hida Takayama International Association 2011). As a result, in 2005, 82 volunteers were ready to guide tourists in twelve languages (Chiiki no karisuma 2005).

In the 1990s, efforts toward Asian markets started with multilingual pamphlets. Making regular visits to Taiwan's annual International Tourism Fair since 1998, to Korean fairs since 2001, and Chinese fairs since 2002, Takayama set up its own booth, independent from and preceding national promotion efforts. Inaugurated in 2003, the Hida Takayama Council for the Attraction of Foreign Tourists consists of leading hotels and tourism industry associations. It supports promotion abroad, the reception of foreign travel agents, and projects connected to the Visit Japan Campaign. As a result of these activities, tourists from Asia, especially Taiwan, increased rapidly from 1999 onward (Tsuchida and Hanyu 2006). The Aichi World Exhibition 2005 in nearby Nagoya further attracted international tourists to the central area of Japan.

From 1996, the city combined welfare planning with tourism, as it started to promote a barrier-free town. While universal design generally became a buzzword in Japan, the concept in Takayama was unique as it aimed to eliminate barriers in the realm of physical movement as well as in the language sector, under the slogan of "A town comfortable to live in is a town comfortable to travel in". Regular monitor tours were conducted to ensure that services and facilities meet the needs of users.

While the public sector took the lead in removing language barriers, efforts extend to the private sector, too. Most recently, in 2009, the city started a new project to support private tourism enterprises when they create pamphlets, signs, or menus in foreign languages.

Throughout this development process, a strong cooperative structure between public and private sector through several tourism promotion organizations and a close connection between the tourism association and the city administration can be identified as one constant feature. Concerning inbound tourism, while the city has embarked on almost all national policies such as the designation of International Tourism Model Districts in the 1980s and the Visit Japan Campaign of recent years, Takayama's efforts precede or extend beyond these policies. The 
concept of a barrier-free city easy to be lived in not only by handicapped and elderly people but also by foreigners - at least as tourists - was an innovative idea that, due to its consequences, sets the city visibly apart from other destinations when tourists navigate through town following multilingual signage embedded in the streets and walking on level sidewalks without curbs.

\section{Differences between foreign and Japanese tourists}

International tourists show some clear differences to Japanese. They visit in different seasons, during weekdays, and often stay for several nights. However, to constitute a real diversification of the tourism market and thus contribute to the rejuvenation of a destination, the existence of different motivations and destination images needs to be confirmed. Therefore, a survey was conducted in November 2010 in Takayama. The analysis of the 410 respondents was based on three groups: first, those who filled out the Japanese questionnaire and had almost exclusively Japanese nationality (245 respondents); second, those who chose the English questionnaire (106 respondents); and, third, those who chose one of the Asian languages (59 respondents). Respondents to the English survey included 67 visitors from different European countries, which proved the increasing importance of this market and is also visible in Takayama's tourism statistics. Respondents to Asian-language surveys included 44 from China, 14 from Taiwan/ Hong Kong/Macao, and 3 from Korea.

Differences between these three groups and between gender were analyzed using the chi-squared test for questions with multiple answers, the Mann-Whitney $U$ test, and the Kruskal-Wallis test for scaled answers. While few significant differences between male and female respondents could be identified, many items proved to differ profoundly between the three groups labeled "Japanese", "English", and "Asian" after the survey language.

The three groups of respondents visited different places in connection with their stay in Takayama, cited different purposes for their visit, and stopped by different attractions inside the city. For example, respondents to the English survey showed a strong interest in history and culture, while Asian tourists gave nature and hot springs as their main purpose. Tourists from the English group visited facilities and locations scattered throughout the historic center, including the Hida no Sato folklore museum, while Asian visitors concentrated on the main street of the historic district and two of the new museums in the suburbs that are included in some bus tours. 


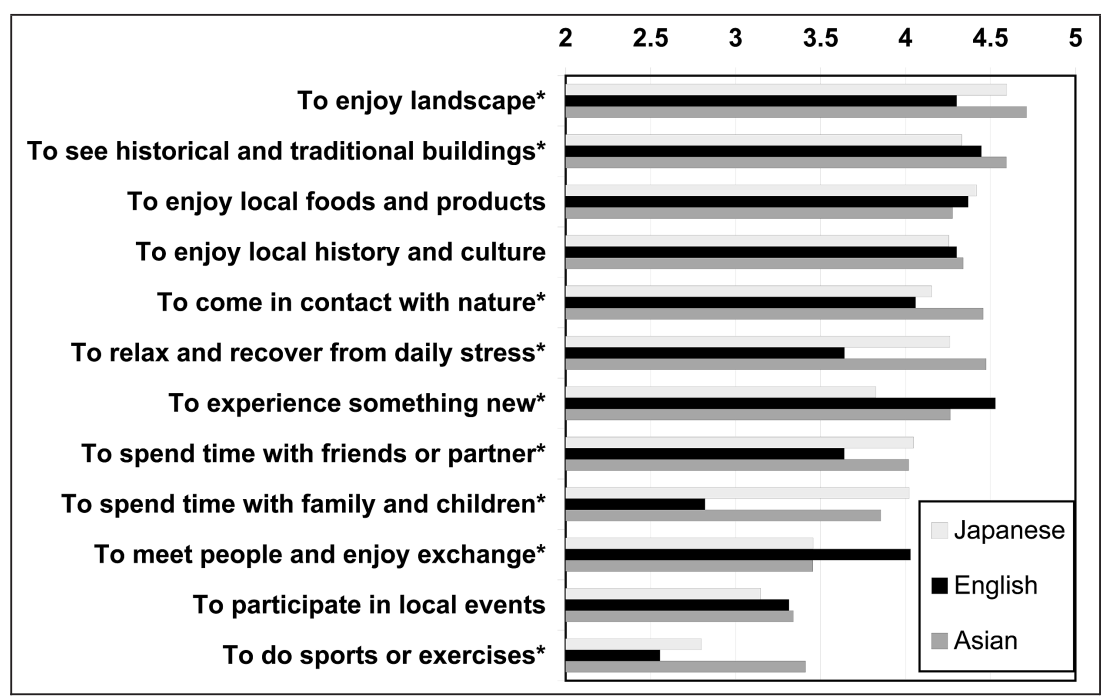

Figure 5. Motivations for travel (average score on five-point scale; 5 = "strongly agree").

Note: $*=$ items with a significant difference at the $5 \%$ level.

Source: Author's own survey.

Asked about their motivation for traveling on a scale from 1 (= "strongly disagree") to 5 (= "strongly agree") (see Figure 5), the highest averages were scored by "to enjoy landscape" (4.54), "to see historical and traditional buildings" (4.4), "to enjoy local foods and products" (4.38), and "to enjoy local history and culture" (4.28). The English group was significantly more interested "to meet people and enjoy exchange" and "to experience something new", while the Asian group showed a stronger interest in "to come in contact with nature" and "to do sports or exercises". The Japanese and the Asian group both had high averages in the items "to enjoy landscape", "to relax and recover from daily stress", and "to spend time with family and children". A strong motivation to experience new places and people clearly contrasts with a more relaxing and family-oriented approach among visitors from within Japan or nearby countries. Emphasis on landscape and nature by the Asian group confirms results of the JNTO survey of 2009 (JNTO 2010a: 109), where expectations of natural landscapes and rustic scenery are very high among tourists from China and Taiwan.

To examine the image as a tourist destination, the survey asked about opinions on Takayama. Sixteen items were presented and respondents expressed their opinion on the same five-point scale used 


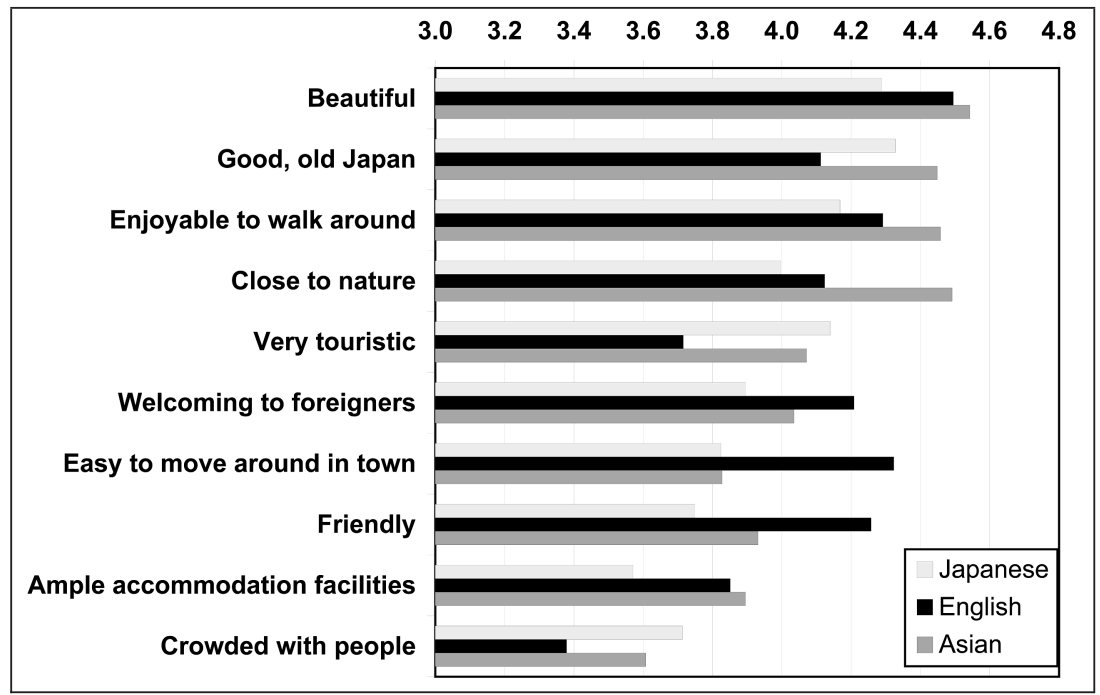

Figure 6. Opinions on Takayama (average score on five-point scale; 5 = "strongly agree").

Note: Only items with a significant difference at the 5\% level.

Source: Author's own survey.

for motivation. On ten items, significant differences could be observed; only these are shown in Figure 6. The Asian and Japanese group shared a common strong perception of Takayama as "good, old Japan", but at the same time noticed it being very touristic and crowded. The latter may be due to the fact that the English group visited more attractions outside the central townscape district, whereas Japanese and Asian tourists mainly stayed in the most crowded area. Actually, the only two items where Japanese had the highest average among all three groups were "very touristic" and "crowded with people". The Asian group found the fact that Takayama is enjoyable to walk around and close to nature more impressive than the other two groups, while the English group thought the city is "welcoming to foreigners", "easy to move around", and "friendly". All foreigners thought it was a beautiful location with ample accommodation facilities.

From the analysis of motivation and image of the destination, clear differences between the three groups of tourists could be seen. Different motivations mean that tourists will enjoy different attractions and facilities. The English group especially showed a strong interest in new experiences and encounters, which corresponds with a wider range of attractions visited in and around Takayama and a longer period of stay. 
The increase in inbound tourism in Takayama and the fact that it is based on a variety of source markets clearly contribute to the rejuvenation of the destination not only in quantitative but also in qualitative aspects. The next section will consider how the tourism industry has engaged with such various needs of inbound tourists.

\section{Innovation in tourism industry}

City policies to promote inbound tourism have been supported by the tourism industry in Takayama, whose main body is formed by accommodation, shops, and tourism facilities (including museums). The number of accommodation facilities has shrunk from 153 in 1990, the first year from which data are available, to 90 in 2010. Overall capacity has also been reduced from a peak of 10,124 persons in 2001 to 8,830 in 2010 (Takayama-shi Shōkō Kankō-bu Kankō-ka 2011), as better access by car has increased the percentage of day-trip visitors. However, capacity per facility has increased from 56 persons in 1990 to 98 in 2010, proof of the gradual replacement of older, smaller facilities through medium-scale newer ones. Minshuku and ryokan provided $64 \%$ of capacity in 1990 , but only $39 \%$ in 2005 , showing the shift from Japaneseto Western-style accommodation. Such a shift in size and style is common throughout Japan. In Takayama, however, it is possible to see a finer process of differentiation between individual facilities. Unfortunately, after 2005, statistics provide no information on types of facilities.

In 2011, the English homepage of the Hida Takayama Ryokan and Hotel Association included three international tourist hotels with more than 200 rooms, 12 city and business hotels, 22 ryokan, and 4 pensions; 17 facilities listed on the Japanese site do not appear on the English version. In an analysis from 2009 (Dai 2009: 115), among 43 listed accommodation facilities, 12 facilities with less than 30 rooms, seven with 30 to 99 rooms, and five with more than 100 rooms had English Web sites; only three in the middle and larger category had Chinese information. Western tourists apparently are quite important for small facilities, while Chinese prefer larger establishments. The Takayama Minshuku Cooperative Society includes 26 facilities both on its Japanese and its English site, of which ten have their own English Web site. According to the president of the society, when Japanese tourists started to flock to Takayama in the 1970s, difficult access made an overnight stay almost essential, and minshuku that used to cater mainly to construction workers and other business-related visitors saw an increase in sightseeing tourists. Some then took in foreign tourists, too. At present, about ten minshuku in Takayama accept foreigners, but only three or four actively recruit international tourists. 
Nowadays, accommodation popular among foreign visitors in Takayama cover a wide range: classical ryokan, traditional minshuku, budget inns, resort hotels popular with tour groups, and new business hotels conveniently located in front of the station. Japanese-style facilities are attractive for foreigners as they offer a new, different experience. However, it has been pointed out frequently that futons and Japanese-style toilets are difficult to handle, the usual set prices for rooms including meals allow no flexibility, and the contents of meals cannot be chosen freely, so innovations might be required. Interviews conducted with accommodation facilities in Takayama that have a large percentage of foreign visitors give some conclusions about their approaches to the inbound market. The following three facilities represent different periods and styles of adaption to inbound tourism.

Facility A is a minshuku with seven Japanese-style and two Westernstyle rooms in a simple modern building, currently run in the third generation. Rooms and meals can be booked separately. In the late 1980s, the owner was approached by the city tourism department to join the Japanese Welcome Inn Group, an accommodation association that actively tries to attract foreign tourists. Conditions set by the group include lockable rooms, Western-style toilets and showers - though not in each room - and efforts to communicate in English. Although the owner had no other experience than school English, he decided to "give it a try", as he was interested in foreign cultures. Through joining this group, he also experienced the advantages of the Internet and asked a friend to create a Web site for his facility as early as $1996 . \mathrm{He}$ then proceeded to create an English Web site for the Takayama Minshuku Cooperative Society. His own Web site currently includes nine languages. The Internet is more important for his business than guidebooks in attracting guests, and through blogs of customers and by joining pay sites, he has managed to become very visible in search engines. Mails are his main form of reservation as they allow him to answer to special needs. To adjust to the needs of foreigners, he has installed a computer for guests with free Internet access, provides direct international phone service from all rooms and large bath towels instead of the usual small Japanese towels, and answers to requests for special meals for vegetarians and others. Guests include many Western visitors, but also young people from Asian countries. Foreign tourists offer many advantages, as they reserve very early and visit on weekdays when there are few Japanese travelers. They need less information as they have a very clear image of what they want to do and where they want to go. They also create a positive image of the facility and attract Japanese tourists who want to enjoy the international atmosphere. Small troubles do occur occasionally, and sudden changes of plan or 
cancellations are a problem, but on the whole, the facility has profited greatly from foreign tourists.

Facility B is a ryokan with 18 rooms. The owner replaced the former concrete structure built in 1977 with a 150-year-old Japanese-style building in 1991 to offer visitors to Takayama a traditional experience. As a consequence, his guests changed from tour groups booked through travel agents to individual tourists such as middle-aged couples and small groups of women. When the ryokan was introduced in one of the major English guidebooks without the owner even knowing it, foreigners started coming; it was not until around 2005 that he established an English Web site. With the number of foreigners increasing steadily since about 1999, they now account for more than $60 \%$ of his guests. Since prices are higher than in a minshuku, visitors arrive mainly from Western countries. To adjust to their needs, the owner offers information material created by the city and puts up posters to explain the Japanese way of bathing or making tea. Although he experiences a lot of trouble with special food requests, mistakes in using the bath, and guests entering the house in shoes, international tourists now form an indispensable part of business, especially since they travel in Japanese in off-season and stay for several days. To better promote Takayama abroad, he joined a group of several accommodation facilities and together set up a professional site with reservation service and information on dining and sightseeing. Although the facility was first introduced to foreigners without the owner knowing about it, he made active use of the new target group. The fact that he can offer a traditional Japanese-style experience helps to fight growing competition by new business hotels.

Facility C was established in 1994 to cater especially for international tourists as an inn without special services but reasonable prices. A lounge and a small kitchen provide opportunities to meet other travelers and prepare simple food. The owner, who came from Takayama originally but had worked for many years as a translator in Tokyo, had experienced the need for simple, cheap accommodation facilities where guests can stay for several nights when she visited Takayama with foreign guests as a translator. For the facility, she made use of a building situated in the entertainment district of Takayama City. She immediately set up a Web site but has kept the content as simple as possible. The inn is featured in many foreign guidebooks, including Lonely Planet and Michelin. Although she had no experience in running an accommodation business, she was able to put her rich knowledge as a traveler to use. Her staff all speak at least some English, and the owner herself is featured in one guidebook as "outgoing" and a "mine of information" (Michelin 2010: 412). Besides the inn, she also runs a 
unique facility called Teddy-bear Eco Village near the open-air museum, a teddy-bear-themed attraction housed in two traditional Japanese buildings. The reuse of old buildings for the facility and old materials for wallpaper and furniture along with solar-generated electricity are some of its ecological features, principles that also can be seen in the management of the inn with simple services and no individual bathrooms.

Facility A can be considered a veteran in inbound tourism which adjusted early with small changes for the needs of foreign tourists. Facility B came across it much later and rather by chance, but has since taken an active attitude. The owner of Facility $\mathrm{C}$ has introduced a new style of accommodation to Takayama, backed by experiences abroad. While all three have actively embraced the possibilities of Internet PR and reservation, direct mail remains an important source for contact with visitors, as the personal element is central for small facilities. Inbound tourism has contributed to the survival of traditional accommodation as well as to the diversification of facilities; however, the reliance on foreign visitors also has a strong element of risk. All three owners mentioned fluctuation in the origin of tourists, fluctuations that they were not able to explain; and the triple catastrophe of 11 March 2011 brought inbound tourism almost to a standstill for several months.

As with accommodation facilities, concentrations of foreign guests can be observed in restaurants and shops, too. In a survey of 100 businesses conducted by the author in 2010, which included mainly shops but also restaurants and small tourism facilities, the average percentage of foreign customers was $27 \%$, but a few shops recorded it as high as $70 \%$ to $80 \%$. Among foreigners, Chinese-speaking visitors were dominant in the central townscape area with its many souvenir shops, while English and other European languages were the strongest market in the quieter townscape areas and along the shopping arcades also used by local customers. However, the range of innovative approaches was quite limited: 20 respondents mentioned no activities at all, 54 businesses try simple conversation in foreign languages, 42 use foreign language for their signs and menus, 31 offer foreign-language pamphlets provided by the city, 21 accept credit cards, 20 have an English Web site or pamphlet, 15 speak to customers in foreign languages, and 12 hire staff with language abilities. Reasons given for these approaches were the fact that the number of foreign visitors increased (67 respondents), that they wanted foreign tourists to be satisfied (46 respondents) and receive a positive impression of Takayama (36 respondents). From this response, the motivation of reacting to rising numbers is clearly predominant, but a strong sense of active hospitality is also visible. Asked about the direction of future tourism policies, 60 respon- 
dents hoped to increase the numbers of both Japanese and foreign tourists, while 22 opted for an increase in Japanese and only three for an increase in foreigners. European languages other than English were seen as the most favorable market, as more and more French, Spanish, and Italian tourists have visited Takayama in recent years. In general, the increase in international tourists was seen as positive, but some remarks about bad manners or little willingness to spend money were also recorded.

If the fact that two-thirds of the businesses responding to the survey had been in business for more than ten years is taken into account, the rather passive approach seems understandable as foreign tourists only form the most recent layer in an ever-changing customer composition. Compared to the examples taken from the accommodation sector, single actors in accommodation facilities with a strong involvement in inbound tourism and the larger group of small businesses clearly differ in the degree they actively adapt their services and facilities to foreign tourists.

\section{Conclusion}

If we compare the development of Hida Takayama as a tourist destination in general with the steps of TALC, we can identify the stages of "Exploration", "Involvement", and "Development" until the early 1980s. After a phase of "Stagnation", the establishment of a cooperative structure between public and private sectors and the beginning of inbound tourism promotion started a long-term period of "Consolidation", which included a series of small cycles of "Stagnation" and "Rejuvenation". Focusing on inbound tourism only, an almost constant increase in the number of foreign visitors and an expansion in their regions of origin prove that it has served as a stabilizing segment of the overall tourism market so far. As mentioned above, Agarwal (2002) groups rejuvenation strategies into product reorganization through investment, technical change, coordination of strategies, and product specialization on the one hand, and product transformation through service quality enhancement, environmental quality enhancement, repositioning, diversification, collaboration, and adaption on the other. While strategies for product specialization play a minor role, what could be identified clearly is collaboration between private and public sectors, enhancement of environmental quality through townscape protection and universal design, service quality enhancement through specialized services for foreign tourists, diversification from domestic to foreign tourists and then to different regions of origin through promotion and multilingual information, as well as adaption to the needs of 
foreign tourists in the tourism industry. The survey of tourists proved that they differ from Japanese tourists and among different market segments in behavior, motivation, and destination image, so attracting foreign tourists from different regions of origin can be considered a valuable strategy for diversification. Concerning repositioning, the merger of Takayama City with surrounding communities in 2005 brought more "natural" elements and hot springs into the city area and will require image integration and repositioning in the future. However, this process is still under way and outside the scope of this paper.

Innovation has occurred on several levels. In policies, the concept to include language barriers in universal design was an innovative idea, although born to a certain degree from the necessity to appeal to citizens more interested in welfare than in tourism policies (Tsuchida and Hanyu 2006: 443). Designs developed from this concept are highly visible throughout town and have become the target of visiting observation groups. In the private sector, the addition of new museums in the 1990s added some unique facilities, but very few appeal to foreign tourists. Different styles of accommodation facilities in recent years mostly imported well-tested types of facilities, but the budget inn (Facility C) specifically appealing to foreign tourists was unique at the time of establishment. In the accommodation sector, some facilities actively appeal to foreign tourists and develop their product accordingly. Small private enterprises, especially shops, tend to employ strategies of adaption that rely on material provided by the city. Interest in promoting inbound tourism differs by location of the business inside the city and by origin of visiting tourists.

Public-private cooperation, concentration on promotion in certain markets, gathering and sharing information on these markets, a coherent strategy connecting efforts abroad and at the destination are some of the elements listed by JNTO (2006: 12) as common features of destinations successful in the inbound market. Takayama has so far implemented many of these elements, thus preceding and expanding national inbound policies. It is now an international tourist destination where tour groups from Taiwan or other Asian countries share the traditional townscape with individual travelers from Europe or America. The fact that foreign - especially western - tourists are highly visible in the streets of Takayama further adds to the attraction of the city for domestic tourists.

On the basis of the discussion above, a conclusion written at the beginning of 2011 would have pointed out that inbound tourism has considerable innovative potential for a destination in the process of rejuvenation or stabilization. It might have emphasized that it is important to strive for a diverse range of visitors from different regions and 
countries, and that care is required to spread the positive effects more evenly among the local tourism industry. Taking the accommodation sector as an example, inbound tourism in Takayama is in the development stage, where a small number of active individuals promote innovations, which then spread through policy support, industry associations, and personal contacts to other businesses. Inbound tourism is perceived as a positive factor in the city and has contributed to the image of Takayama as an attractive destination nationwide. While international tourists still account for little more than $10 \%$ of all overnight stays, their different travel patterns and motivations induce farreaching effects and have created a specialized sector of tourism businesses. Even core facilities such as the open-air museum Hida no Sato and one of the new museums now heavily rely on foreign visitors.

Unfortunately, since 11 March 2011, inbound tourism shrunk by $50.3 \%$ in March, $62.5 \%$ in April, and $50.4 \%$ in May compared with 2010. The area damaged by earthquake, tsunami, and radiation received few foreign tourists even before the disaster; however, the longlasting effects of radiation are impossible to calculate. It could be argued that innovative clusters in a new sector will be more vulnerable to fluctuations of a still unstable customer base. After all, international tourism has been shaken in recent years by a variety of events including real or perceived epidemics, wars, and volcanic ash. However, in this case, domestic tourism is also affected, as can be seen from the fact that the Hida Takayama Ryokan and Hotel Association (2011) started to offer a special discount package on its Japanese site for all visitors until the end of July. Tourism as an industry is vulnerable to "droughts", and support plans for sudden, short-term drops in visitor numbers as well as information strategies should be included in destination management policies. In the meantime, day-trip visitors from surrounding areas enjoy a quiet, less crowded Takayama. As for international tourists, repeat visitors who have a clearer picture of distances and realities in Japan will probably come back first. Diversification of source markets and tourist types still is the key factor to continuously rejuvenate a destination.

Carolin Funck earned a doctoral degree at Albert-Ludwigs University Freiburg (Germany) and is now Associate Professor for Human Geography at Hiroshima University (Japan), Graduate School of Integrated Arts and Sciences. Her research focuses on the development of tourism in Japan, the rejuvenation of mature tourist destinations, on machizukuri and citizen participation. 


\section{References}

Agarwal, Sheela. 2002. Restructuring seaside tourism. The resort life cycle. Annals of Tourism Research 29 (1). 25-55.

Butler, Richard W. 1980. The concept of a tourist area cycle of evolution: Implication for management of resources. Canadian Geographer 24. 5-12.

Chiiki no karisuma [Regional charisma]. 2005. Hida Takayama kankō kyōkai kaichō Minotani, Takashi [Hida Takayama Tourism Association president Takashi Minotani]. Nikkei Gurōkaru 30 (20 June). 50-51.

Cooper, Chris. 2006. The anatomy of the rejuvenation stage of the TALC. In R. W. Butler (ed.), The tourism area life cycle. Vol. 2: Conceptual and theoretical issues, 183-200. Clevedon, Buffalo \& Toronto: Channel View Publications.

Dai, Junko. 2009. Inbound tourism promotion in Takayama City. Proceedings of Japan Institute for Tourism Annual Conference 2009, 113-116.

Funck, Carolin. 1999. Tourismus und Peripherie in Japan. Über das Potential touristischer Entwicklung zum Ausgleich regionaler Disparitäten. Bonn: Verlag Dieter Born.

Hall, C. Michael \& Allan Williams. 2008. Tourism and innovation. London: Routledge.

Hida Takayama International Association. 2011. http://www.htia.org/e/htia/index.html (accessed 6 June 2011).

Hida Takayama Ryokan and Hotel Association. 2011. Ganbarō! Nippon. http://www.takayamaryokan.jp/plan (accessed 14 June 2011).

Hida Takayama-shi Tōkyō Jimushō. 2006. Hida Takayama zainichi gaikokujin monitā ryokō jisshi hōkokusho [Report on the monitor tour in Hida Takayama by foreign residents of Japan]. Takayama: Hida Takayama-shi Tōkyō Jimushō [Hida Takayama City, Tokyo Office].

Hjalanger, Anne-Mette. 2002. Repairing innovation defectiveness in tourism. Tourism Management 23. 465-474.

JNTO. 1999. Statistics of tourism for Japan. Tokyo: International Tourism Center of Japan.

JNTO. 2004. Statistics of tourism for Japan. Tokyo: International Tourism Center of Japan.

JNTO. 2006. JNTO hōnichi ryokō yūchi handobukku 2005/2006 [Handbook for attracting foreign trips to Japan]. Tokyo: International Tourism Center of Japan.

JNTO. 2009. Statistics of tourism for Japan. Tokyo: International Tourism Center of Japan.

JNTO. 2010a Hōnichi gaikyaku hōmonchi chōsa 2009 [Destination survey of overseas visitors to Japan 2009]. Tokyo: International Tourism Center of Japan.

JNTO. 2010b. Statistics of tourism for Japan 2009. Tokyo: International Tourism Center of Japan.

Lagiewski, Richard M. 2006. The application of the TALC model: A literature survey. In Richard W. Butler (ed.), The tourism area life cycle. Vol. 1: Applications and modifications, 27-50. Clevedon, Buffalo \& Toronto: Channel View Publications.

Lonely Planet (ed.). 2007. Japan. London: Lonely Planet Publications.

Kitamura, Takashi. 2007. Inbaundo tsūrizumu no genjō to kadai [Situation and problems of inbound tourism]. Matsukage Daigaku Kiyō 7. 123-132.

Michelin (ed.). 2010. Michelin's green guide to Japan. London: Michelin Apa Publications.

MLIT (Ministry of Land, Infrastructure, Transport, and Tourism) Tourism Agency. 2009. Ryokō/kankō sangyō no keizai kōka ni kansuru chōsa kenkyū 9 [Research 
on the economic effects of the travel/tourism industry 9].

http://www.mlit.go.jp/common/000108449.pdf (accessed 17 March 2012).

MLIT. 2007-2011. Shukuhaku ryokō tōkei chōsa [Overnight trip statistics survey].

MLIT Tourism Agency. 2010a. Shukuhaku ryokō tōkei chōsa [Overnight trip statistics survey]. http://www.mlit.go.jp/kankocho/siryou/toukei/shukuhakutoukei.html (accessed 25 May 2011).

MLIT Tourism Agency. 2010b. Kankō karisuma ichiran: Minotani, Takashi [List of tourism charisma personalities: Mr. Takashi Minotani].

http://www.mlit.go.jp/kankocho/shisaku/jinzai/charisma/mr_minotani.html (accessed 25 September 2011).

Soshiroda, Akira. 2005. Inbound tourism policies in Japan from 1859 to 2003. Annals of Tourism Research 32 (4). 1100-1120.

Takayama-shi Shōkō Kankō-bu Kankō-ka. 2011. Kankō tōkei [Tourism statistics]. Takayama: Takayama-shi Shōkō Kankō-bu Kankō-ka [Takayama City, Department for Commerce, Industry and Tourism; Tourism Section].

Tanizawa, Akira. 2005. Rekishi, fūdo, bunka o ikashita chiiki zukuri ni kansuru kenkyū [Research on regional development through history, topography, and culture]. Aichi Shukutoku Daigaku Ronshū. Gendai Shakai Gakubu, Gendai Shakai Kenkyüka-hen [Aichi Shukutoku University essay collection. Modern Society Department, Modern Society research edition] 10. 31-50.

Tsuchida, Yumeko \& Fuyuka Hanyu. 2006. The transition of resident's opinion about tourism-based community development in articles on local newspaper "Takayama Shimin Jiho". Journal of the City Planning Institute of Japan 41 (3). 439-444.

Tsuda, Keiichi. 2004. Kokusai kankō toshi o mezashita Hida Takayama no torikumi [Efforts of Hida Takayama with the aim to become an international tourist city]. Unyū to Keizai 64 (5). 39-44. 
